\title{
The Endogenous Cannabinoid Anandamide and Its Synthetic Analog $R(+)$-Methanandamide Are Intravenously Self-Administered by Squirrel Monkeys
}

\author{
Zuzana Justinova, ${ }^{1}$ Marcello Solinas, ${ }^{1,3}$ Gianluigi Tanda, ${ }^{2}$ Godfrey H. Redhi, ${ }^{1}$ and Steven R. Goldberg ${ }^{1}$ \\ ${ }^{1}$ Preclinical Pharmacology Section, Behavioral Neuroscience Research Branch and ${ }^{2}$ Psychobiology Section, Medications Discovery Research Branch, \\ Intramural Research Program, National Institute on Drug Abuse, National Institutes of Health, Department of Health and Human Services, Baltimore, \\ Maryland, 21224, and ${ }^{3}$ Laboratoire de Biologie et Physiologie Cellulaire, Université de Poitiers, 86022, Poitiers, France
}

Anandamide, an endogenous ligand for brain cannabinoid $\mathrm{CB}_{1}$ receptors, produces many behavioral effects similar to those of $\Delta^{9}$ tetrahydrocannabinol (THC), the main psychoactive ingredient in marijuana. Reinforcing effects of THC have been demonstrated in experimental animals, but there is only indirect evidence that endogenous cannabinoids such as anandamide participate in brain reward processes. We now show that anandamide serves as an effective reinforcer of drug-taking behavior when self-administered intravenously by squirrel monkeys. We also show that methanandamide, a synthetic long-lasting anandamide analog, similarly serves as a reinforcer of drug-taking behavior. Finally, we show that the reinforcing effects of both anandamide and methanandamide are blocked by pretreatment with the cannabinoid $\mathrm{CB}_{1}$ receptor antagonist rimonabant (SR141716). These findings strongly suggest that release of endogenous cannabinoids is involved in brain reward processes and that activation of cannabinoid $\mathrm{CB}_{1}$ receptors by anandamide could be part of the signaling of natural rewarding events.

Key words: anandamide; cannabinoids; methanandamide; reinforcing effects; self-administration; squirrel monkey

\section{Introduction}

Anandamide, the first identified endogenous ligand for brain cannabinoid receptors (Devane et al., 1992), activates cannabinoid $\mathrm{CB}_{1}$ receptors in the brain and produces many behavioral effects similar to, but less intense than, those of $\Delta^{9}$ tetrahydrocannabinol (THC) (Smith et al., 1994). Compared with THC, anandamide has a different chemical structure, a lower potency at cannabinoid $\mathrm{CB}_{1}$ receptors, and a much shorter duration of action in vitro and in vivo as a result of rapid two-step inactivation by reuptake into neurons via presumed membrane transporters and subsequent intracellular degradation by fatty acid amide hydrolase (FAAH) (Freund et al., 2003; Piomelli, 2003). Most, but not all, pharmacological effects of THC are effectively inhibited by the $\mathrm{CB}_{1}$ receptor antagonist rimonabant (Rinaldi-Carmona et al., 1994), and rimonabant precipitates withdrawal signs in experimental animals chronically treated with THC (Ledent et al., 1999; Maldonado and Rodriguez de Fonseca, 2002; Tanda and Goldberg, 2003). In contrast, there are conflicting reports on the ability of rimonabant to inhibit behavioral actions of anandamide in rodents (Adams et al., 1998; Costa

Received March 10, 2005; revised May 6, 2005; accepted May 7, 2005

This work was supported by the Intramural Research Program of the National Institute on Drug Abuse, National Institutes of Health, Department of Health and Human Services. We thank Drs. Daniele Piomelli and Alexandros Makriyannis for helpful suggestions and comments while conducting this research.

Correspondence should be addressed to Dr. Steven R. Goldberg, Preclinical Pharmacology Section, Behavioral Neuroscience Research Branch, National Institute on Drug Abuse, Intramural Research Program, National Institutes of Health, 5500 Nathan Shock Drive, Baltimore, MD 21224. E-mail: sgoldber@intra.nida.nih.gov.

DOI:10.1523/JNEUROSCI.0951-05.2005

Copyright $\odot 2005$ Society for Neuroscience $\quad$ 0270-6474/05/255645-06\$15.00/0 et al., 1999) and to precipitate withdrawal signs in rats chronically treated with anandamide (Aceto et al., 1998; Costa et al., 2000). Also, anandamide still produces cannabimimetic effects in cannabinoid $\mathrm{CB}_{1}$ receptor knock-out mice (Di Marzo et al., 2000b). Finally, anandamide does not generally produce THC-like responding in monkeys and rats in drug-discrimination studies, although its longer-lasting, metabolically stable, synthetic ana$\operatorname{logs} R(+)$-methanandamide (methanandamide) (Abadji et al., $1994)$ and O-1812 [(R)-(20-cyano-16,16-dimethyl docosa-cis5,8,11,14-tetraenoyl)-1'-hydroxy-2'-propylamine] do show cross-discrimination with low doses of THC in rats (Jarbe et al., 2001; Maldonado and Rodriguez de Fonseca, 2002; Tanda and Goldberg, 2003; Wiley et al., 2004), suggesting that difficulties in demonstrating THC-like behavioral effects of anandamide may be attributable to its rapid inactivation and short duration of action rather than to qualitative differences between anandamide and THC. Most of these observations contribute to expectations that various means of facilitating the actions of endogenous anandamide for therapeutic purposes (Piomelli, 2003, 2004; Di Marzo et al., 2004) would have minimal abuse liability, although there have been no reported attempts to assess reinforcing effects of anandamide directly, with the exception of one negative finding with intraperitoneal anandamide using a conditioned place preference procedure in rats (Mallet and Beninger, 1998).

Although reinforcing effects of THC have been clearly demonstrated in experimental animals (Tanda et al., 2000; Justinova et al., 2003), there is only indirect evidence that endogenous cannabinoids such as anandamide participate in brain reward pro- 
cesses (van der Stelt and Di Marzo, 2003). For example, we found recently that anandamide and its longer-lasting, metabolically stable synthetic analog methanandamide increase extracellular dopamine levels in the shell of the nucleus accumbens, a marker of reinforcing effects for most drugs abused by humans (M. Solinas, Z. Justinova, S. R. Goldberg, and G. Tanda, unpublished observations). Here we directly investigated the reinforcing effects of anandamide and methanandamide using a primate model of human drug abuse previously used successfully with THC (Tanda et al., 2000; Justinova et al., 2003) and other abused drugs (Goldberg, 1973).

\section{Materials and Methods}

Subjects. Nine adult male squirrel monkeys (Saimiri sciureus) weighing $0.9-1.1 \mathrm{~kg}$ were housed in individual cages in a temperature- and humidity-controlled room with access to water ad libitum. Monkeys were fed ( $\sim 2 \mathrm{~h}$ after the session) a daily food ration consisting of five biscuits of high-protein monkey diet (Lab Diet 5045; PMI Nutrition International, Richmond, IN) and two pieces of Banana Softies (BioServ, Frenchtown, NJ) that maintained their body weights at a constant level throughout the study. Fresh fruits, vegetables, and environmental enrichment were provided daily. Monkeys were maintained in facilities fully accredited by the Association for Assessment and Accreditation of Laboratory Animal Care, and experiments were conducted in accordance with guidelines of the Institutional Care and Use Committee of the Intramural Research Program, National Institute on Drug Abuse, National Institutes of Health, and Guidelines for the Care and Use of Mammals in Neuroscience and Behavioral Research (National Research Council, 2003).

A group of six monkeys was used for experiments with anandamide self-administration: two monkeys were experimentally naive, three had a history of THC self-administration, and one had a history of methohexital self-administration (Table 1). With monkeys 1574, 1568, 6754, and 67F4, daily self-administration sessions at an anandamide dose of 40 $\mu \mathrm{g} / \mathrm{kg}$ per injection were started after any previous drug-taking behavior was extinguished during 5-10 sessions of saline substitution under the 10-response, fixed-ratio (FR10) schedule of intravenous drug injection. One experimentally and drug naive monkey (70F4) was first trained to press a lever for food pellets, and $40 \mu \mathrm{g} / \mathrm{kg}$ intravenous injections of anandamide were then substituted for food, as described previously with THC (Justinova et al., 2003). In the other naive monkey (66B2), $40 \mu \mathrm{g} / \mathrm{kg}$ injections of anandamide were initially made available under conditions in which each press produced an injection (FR1), and the timeout value was $5 \mathrm{~s}$; as the monkey learned to respond, the response requirement was gradually raised to 10 (FR10) and the timeout value to $1 \mathrm{~min}$. For comparison with anandamide, three additional monkeys (01714B, 5045, and 70F7) with stable cocaine self-administration behavior were studied at a cocaine dose of $30 \mu \mathrm{g} / \mathrm{kg}$ per injection that maintains maximal rates of responding under the present schedule conditions (Goldberg, 1973).

Apparatus and self-administration procedure. Experimental chambers and other apparatus used in this study were the same as described previously in detail (Justinova et al., 2003). Monkeys were surgically prepared with chronic indwelling venous catheters (polyvinyl chloride), as described previously (Goldberg, 1973). The monkey's catheter was connected to polyethylene tubing, which passed out of the isolation chamber and was then attached to a motor-driven syringe pump. Before the start of each session, monkeys were placed into the Plexiglas chairs and restrained in the seated position by waist locks. Before the start of each session, catheters were flushed with $1 \mathrm{ml}$ of saline, and one priming injection was delivered (calculated to fill the dead space of the intravenous catheter).

At the start of the session, the white house light was turned off and the green stimulus lights were turned on. In the presence of the green lights, monkeys were required to make 10 responses on the lever (FR10) to produce an injection of anandamide or cocaine. The completion of 10 responses on the lever turned off the green lights and produced an intravenous injection of $40 \mu \mathrm{g} / \mathrm{kg}$ anandamide or $30 \mu \mathrm{g} / \mathrm{kg}$ cocaine paired with a $2 \mathrm{~s}$ illumination of the amber stimulus lights. Duration of each injection was $0.2 \mathrm{~s}$, and injection volume was $0.2 \mathrm{ml}$. Each injection was followed by a $60 \mathrm{~s}$ timeout period, during which the chamber was dark and lever presses had no programmed consequences. One hour sessions were conducted $5 \mathrm{~d} /$ week (typically Monday to Friday).

When responding for $40 \mu \mathrm{g} / \mathrm{kg}$ injections of anandamide was stable for at least five consecutive sessions $(<15 \%$ variability $)$, selfadministration behavior was extinguished by replacing anandamide with its vehicle for five consecutive sessions, followed by replacement of vehicle with $40 \mu \mathrm{g} / \mathrm{kg}$ injections of anandamide for an additional five sessions. Next, an anandamide dose-effect curve was constructed by giving monkeys the opportunity to self-administer a range of anandamide doses $(2.5,10,20,40,80$, and $160 \mu \mathrm{g} / \mathrm{kg}$ per injection). Each anandamide dose was studied for five consecutive sessions, and each dose condition was separated by five consecutive sessions of vehicle extinction. This was followed by determination of a dose-effect curve for methanandamide (doses ranged from 2.5 to $80 \mu \mathrm{g} / \mathrm{kg}$ per injection) in four monkeys (66B2, 1568,6754 , and 1574). Afterward, we studied the effects of $5 \mathrm{~d}$ presession treatment with 0.03 and $0.1 \mathrm{mg} / \mathrm{kg}$ rimonabant or its vehicle (given intramuscularly, 60 min before session) on self-administration of the 40 $\mu \mathrm{g} / \mathrm{kg}$ dose of anandamide and the effects of $0.1 \mathrm{mg} / \mathrm{kg}$ rimonabant on self-administration of the $40 \mu \mathrm{g} / \mathrm{kg}$ dose of methanandamide. Monkeys were injected with vehicle or rimonabant in the chair and were then returned to their home cage.

In the control group of monkeys responding for $30 \mu \mathrm{g} / \mathrm{kg}$ injections of cocaine, self-administration behavior was extinguished by replacing cocaine with its vehicle for five consecutive sessions, followed by replacement of vehicle with $30 \mu \mathrm{g} / \mathrm{kg}$ injections of cocaine. The dose $0.1 \mathrm{mg} / \mathrm{kg}$ rimonabant was then tested for its effects on self-administration of the 30 $\mu \mathrm{g} / \mathrm{kg}$ dose of cocaine.

Drugs. Anandamide ( $\mathrm{N}$-arachidonylethanolamide) was purchased from Tocris Cookson (Ellisville, MI) and was dissolved in a water-soluble emulsion [Tocrisolve; soya oil/water (1:4) emulsion] or in a vehicle containing $0.25-4 \%$ ethanol, $0.25-4 \%$ Tween 80 , and saline. $R(+)$ Methanandamide (AM356; $\mathrm{R}(+)$-arachidonyl-1'-hydroxy-2' propylamide) was purchased from Sigma (St. Louis, MO) and was dissolved in a vehicle containing $0.125-4 \%$ ethanol, $0.125-4 \%$ Tween 80 , and saline. (-)-Cocaine $\mathrm{HCl}$ was purchased from Sigma and was dissolved in saline. Rimonabant (SR141716; N-piperidino-5-(4chlorophenyl)-1-(2,4-dichlorophenyl)-4-methylpyrazole-3-

carboxamide) was provided by the National Institute on Drug Abuse, National Institutes of Health (Rockville, MD) and was dissolved in a vehicle of $2 \%$ ethanol, $2 \%$ Tween 80 , and saline.

Data analysis. Cumulative-response records were obtained during all sessions to assess within-session patterns of responding (see Fig. $3 d-f$ ). Abscissas represent time, and ordinates represent cumulative leverpressing responses. Short diagonal marks on the cumulative records indicate drug injections. After each injection, there was a timeout period, during which the recorder did not operate. Pairs of diagonal hash marks 
represent deleted segments of the records, during which no responding occurred. Rates of responding during self-administration sessions are expressed as responses per second averaged over the $1 \mathrm{~h}$ session, with responding during timeouts not included in calculations. Injections per session represent total number of injections delivered per session. Data for dose-effect curves are expressed as mean response rates and numbers of injections per session \pm SEM over the last three sessions. In addition, total intake of anandamide or methanandamide each session was calculated. Effects of pretreatment with rimonabant on drug selfadministration are expressed as mean \pm SEM of total numbers of injections per session as a function of consecutive daily self-administration sessions. For statistical evaluation of effects of rimonabant or vehicle extinction over consecutive sessions, the last session of vehicle pretreatment was always used as a control value to allow comparisons with subsequent sessions during pretreatment or extinction. Statistical analysis (SigmaStat program; Jandel Scientific, San Rafael, CA) was done using single-factor repeated-measures ANOVA to assess differences between vehicle and test-drug pretreatment conditions or between different doses of anandamide or methanandamide and vehicle. Significant main effects were analyzed further by subsequent paired comparisons to control values using Dunnett's test. Differences were considered statistically significant when $p<0.05$.

\section{Results}

Acquisition, extinction, and reacquisition of anandamide self-administration

The monkeys learned to rapidly and repeatedly press a lever for intravenous injections of $40 \mu \mathrm{g} / \mathrm{kg}$ anandamide (FR10 schedule) during $1 \mathrm{~h}$ daily sessions. By the end of the first week, all monkeys were consistently self-administering anandamide (16-53 injections per session depending on the individual monkey). However, another 2-9 weeks were required for acquisition of stable levels and characteristic "pause and run" patterns of FR leverpress responding under the final schedule conditions. In all of the monkeys, after acquisition, injections of $40 \mu \mathrm{g} / \mathrm{kg}$ anandamide maintained comparable high response rates (mean of $0.76 \pm 0.12$ response per second) and high numbers of self-administered injections each session (47.00 \pm 1.33 injections per session) (Table $1)$. When vehicle injections were substituted for anandamide injections, rates of responding $\left(F_{(5,20)}=7.69 ; p<0.001\right)$, as well as number of injections self-administered per session $\left(F_{(5,20)}=\right.$ 43.58; $p<0.001$ ), decreased dramatically (Fig. 1). When vehicle injections were replaced with $40 \mu \mathrm{g} / \mathrm{kg}$ injections of anandamide, self-administration behavior immediately recovered $\left(F_{(5,20)}=\right.$ 94.45; $p<0.001$ ) (Fig. 1). The control group of monkeys responding for cocaine showed similar decreases in selfadministration behavior when cocaine injections were replaced with vehicle injections (Fig. 1).

\section{Self-administration of anandamide and methanandamide}

Varying the injection dose of anandamide resulted in classic, inverted, U-shaped, dose-effect curves (Fig. 2a,c,e). Anandamide maintained significantly higher rates of responding $\left(F_{(6,24)}=\right.$ 11.93; $p<0.001)$ and higher numbers of injections per session $\left(F_{(6,24)}=16.26 ; p<0.001\right)$ than vehicle, with maximal responding $(0.83 \pm 0.09$ response per second $)$ and nearly the maximal possible number of injections per session ( $48.90 \pm 0.96$ injections per session) maintained by $40 \mu \mathrm{g} / \mathrm{kg}$ anandamide per injection.

Like anandamide, methanandamide maintained high rates and characteristic FR patterns of responding. When vehicle injections were substituted for methanandamide injections, rates of responding $\left(F_{(5,10)}=13.94 ; p<0.001\right)$, as well as number of injections self-administered per session $\left(F_{(5,10)}=10.16 ; p<\right.$ 0.001 ), decreased dramatically (data not shown). Again, after varying the injection dose of methanandamide, inverted
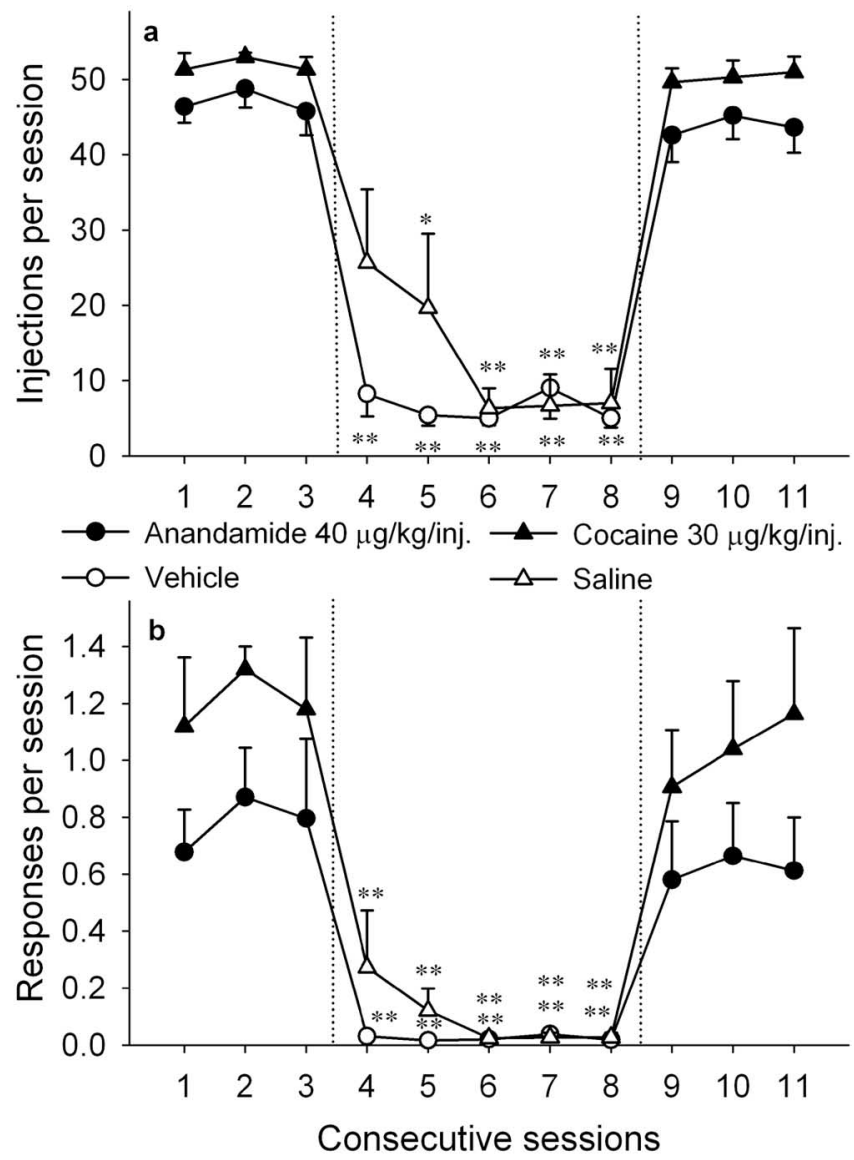

Figure 1. Extinction and reacquisition of anandamide and cocaine self-administration behavior over consecutive sessions. Number of injections per session and overall rates of responding in the presence of a green light during $40 \mu \mathrm{g} / \mathrm{kg}$ per injection of anandamide $(n=5)$ and $30 \mu \mathrm{g} / \mathrm{kg}$ per injection of cocaine $(n=3)$ sessions (sessions $1-3$ and 9-11) and vehicle sessions (sessions $4-8$ ) are shown. Points represent means \pm SEM of injections per session (a) and rates of responding $(\boldsymbol{b}) .{ }^{*} p<0.05,{ }^{* *} p<0.01$, post hoc comparisons with the last session before vehicle extinction.

U-shaped dose-effect curves were found (Fig. 2b,d,f). Methanandamide maintained significantly higher rates of responding $\left(F_{(5,15)}=3.99 ; p=0.017\right)$ and higher numbers of selfadministered injections per session $\left(F_{(5,15)}=13.94 ; p<0.001\right)$ than vehicle at doses of 10,20 , and $40 \mu \mathrm{g} / \mathrm{kg}$ per injection, with maximal rates of responding averaging $0.71 \pm 0.22$ response per second and with a mean of $44.75 \pm 3.21$ injections per session at a dose of $40 \mu \mathrm{g} / \mathrm{kg}$ per injection.

\section{Effects of cannabinoid $\mathrm{CB}_{1}$ receptor blockade on self- administration of anandamide, methanandamide, and cocaine}

A low dose $0.03 \mathrm{mg} / \mathrm{kg}$ rimonabant did not produce significant changes in self-administration behavior for $40 \mu \mathrm{g} / \mathrm{kg}$ anandamide (injections, $F_{(5,15)}=0.84, p=0.545$; rates of responding, $\left.F_{(5,15)}=1.20, p=0.357\right)$. A rimonabant dose of $0.1 \mathrm{mg} / \mathrm{kg}$ significantly decreased the number of self-administered injections of $40 \mu \mathrm{g} / \mathrm{kg}$ anandamide $\left(F_{(5,15)}=11.51 ; p<0.001\right)$ (Fig. $\left.3 a\right)$ or methanandamide $\left(F_{(5,15)}=8.31 ; p<0.001\right)$ (Fig. $\left.3 b\right)$ and rates of responding for anandamide $\left(F_{(5,15)}=20.57 ; p<0.001\right)$ and methanandamide $\left(F_{(5,15)}=8.01 ; p<0.001\right)$. Although selfadministration behavior was significantly reduced by pretreatment with rimonabant, it remained slightly above vehicle substitution levels. In contrast, control monkeys responding for 

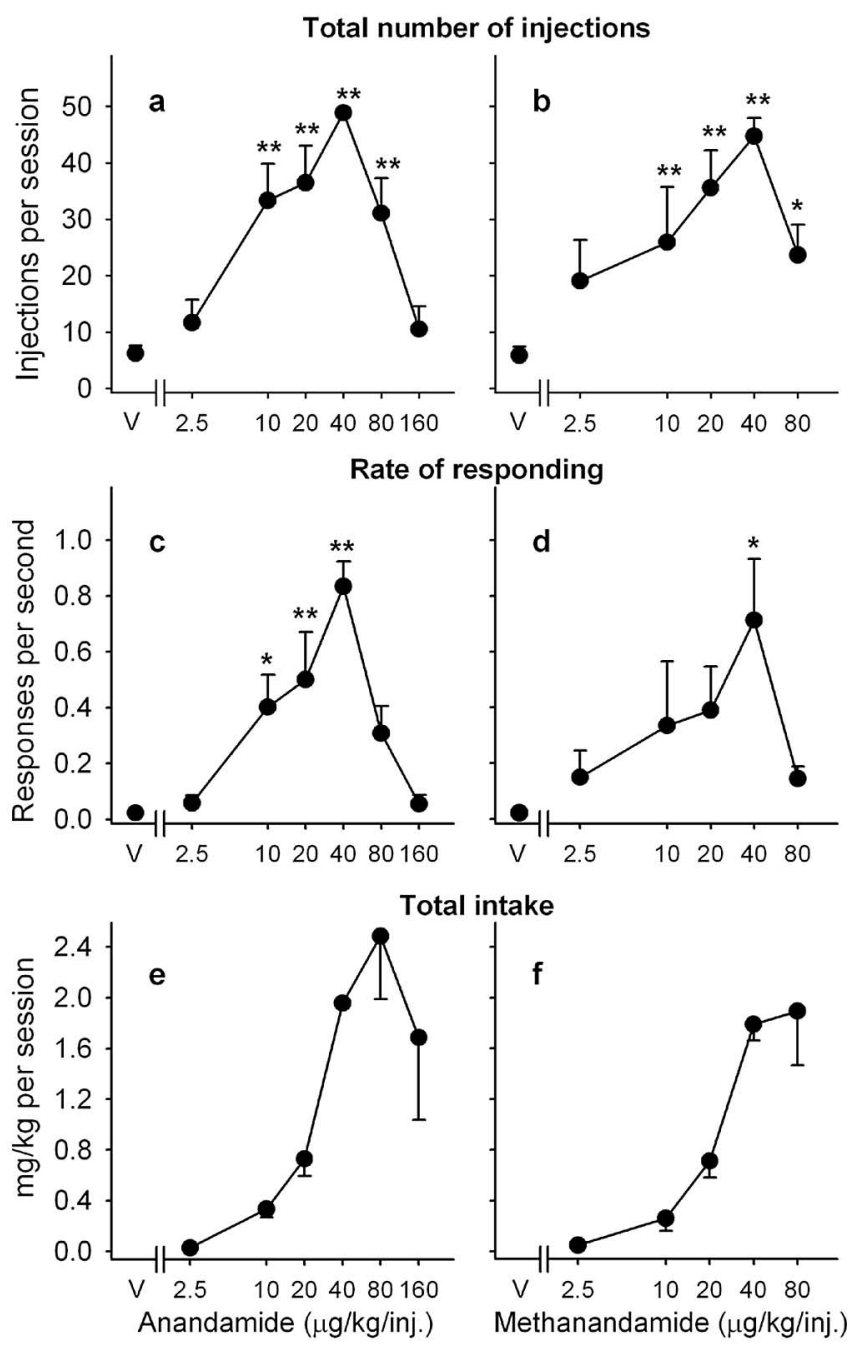

Figure 2. Effects of varying injection dose on self-administration of anandamide and methanandamide. Number of injections of anandamide $(\boldsymbol{a})$ and methanandamide $(\boldsymbol{b})$ per session, overall rates of responding in the presence of the green light signaling anandamide $(c)$ and methanandamide $(\boldsymbol{d})$ availability, and total anandamide $(\boldsymbol{e})$ and methanandamide $(\boldsymbol{f})$ intake per session are shown as a function of injection dose of drug. Each point represents the mean \pm SEM of the last three sessions under each anandamide $(n=5)$ or methanandamide $(n=4)$ unit dose condition and under a vehicle condition. ${ }^{*} p<0.05,{ }^{* *} p<0.01$, post hoc comparisons with the vehicle conditions. V, Vehicle.

cocaine injections showed no significant effect when treated with the $0.1 \mathrm{mg} / \mathrm{kg}$ dose of rimonabant $\left(F_{(5,10)}=1.10 ; p=0.420\right.$ ) (Fig. $3 c$ ), suggesting that the effects of rimonabant were not attributable to nonspecific depressant effects on behavior.

\section{Discussion}

The present experiments yielded three main findings. First, anandamide, like THC, cocaine and other abused drugs, serves as an effective reinforcer of drug-taking behavior when selfadministered intravenously in squirrel monkeys. Rates of responding maintained by anandamide were comparable with those maintained under the same conditions for cocaine in a control group of monkeys in this study $(1.23 \pm 0.17$ response per second and $51.78 \pm 1.09$ injections per session) and by cocaine and THC in our previous studies (Tanda et al., 2000; Justinova et al., 2003).

Second, methanandamide self-administration behavior was virtually identical to that maintained by anandamide, over the same range of injection doses, and intake of methanandamide and anandamide per session was similar despite their marked pharmacokinetic differences. Previous reported differences in behavioral effects of anandamide and methanandamide were found in tasks requiring relatively long-lasting effects over a session, such as discriminative-stimulus effects, disruption of learning, and inhibition of locomotion (Romero et al., 1996; Jarbe et al., 2001). Under those conditions, the brief half-life of anandamide could prevent measurement of significant effects. Conversely, a short duration of effects favors demonstration of a high frequency of self-administered injections under FR10 selfadministration procedures (Ko et al., 2002). In addition, previous marked differences between behavioral effects of anandamide and those of its synthetic analogs methanandamide and O-1812 were found using the intraperitoneal route of administration (Romero et al., 1996; Jarbe et al., 2001; Wiley et al., 2004), whereas in this study, anandamide was delivered intravenously. It is possible that decreased hepatic first-passage metabolism with the intravenous route of administration greatly increased effects of anandamide but not methanandamide, which is resistant to metabolic inactivation by FAAH. This is supported by our recent findings that intravenous injections of anandamide and methanandamide activate dopaminergic neurotransmission in the nucleus accumbens, as measured by extracellular dopamine levels, with similar peak intensity but with different durations of action (Solinas, Justinova, Goldberg, and Tanda, unpublished observations).

Third, the reinforcing effects of both anandamide and methanandamide in squirrel monkeys appear to be mediated by cannabinoid $\mathrm{CB}_{1}$ receptors, because presession treatment with rimonabant dramatically decreased self-administration behavior of both cannabinoids. Rimonabant has been shown previously to block the reinforcing effects of THC (Tanda et al., 2000). It is unlikely that the effects of rimonabant were attributable to nonspecific depressant effects on behavior because rimonabant did not affect responding for a highly reinforcing dose of cocaine in the control group of monkeys and does not depress responding for food under similar conditions (our unpublished observations). These results highlight the fact that, although some of the effect's of anandamide have been attributed to other receptors, such as vanilloid $\mathrm{VR}_{1}$ receptors (Zygmunt et al., 1999) or uncharacterized new non- $\mathrm{CB}_{1}$, non- $\mathrm{CB}_{2}$, cannabinoid receptors (Breivogel et al., 2001; Hajos et al., 2001; Di Marzo et al., 2002; Pertwee, 2004), its reinforcing effects appear to be mediated mainly by cannabinoid $\mathrm{CB}_{1}$ receptors.

Of the many brain neurotransmitters, only a few have been clearly demonstrated to play direct roles in reward processes. Among the endogenous neurotransmitters, dopamine and endogenous opioids are the most clearly involved (Koob and Le Moal, 2001; Wise, 2004). The present findings provide compelling evidence for an important role of endogenous cannabinoids in brain reward processes. Previous studies have shown that cannabinoid $\mathrm{CB}_{1}$ receptor antagonists such as rimonabant can alter the reinforcing effects of abused drugs and food (Solinas et al., 2003; Solinas and Goldberg, 2005). Similar results have been found when cannabinoid $\mathrm{CB}_{1}$ receptors were genetically ablated (Ledent et al., 1999; Sanchis-Segura et al., 2004). Also, chronic treatment with abused drugs leads to changes in brain levels of endogenous cannabinoids in areas involved in motivational and reward processes (Di Marzo et al., 2000a; Gonzalez et al., 2002), and acute administration of a dopamine $\mathrm{D}_{2}$ receptor agonist increases extracellular levels of anandamide in the striatum (Giuffrida et al., 1999), suggesting that abused drugs do, indeed, release endocannabinoids, either directly or indirectly through release of 
a

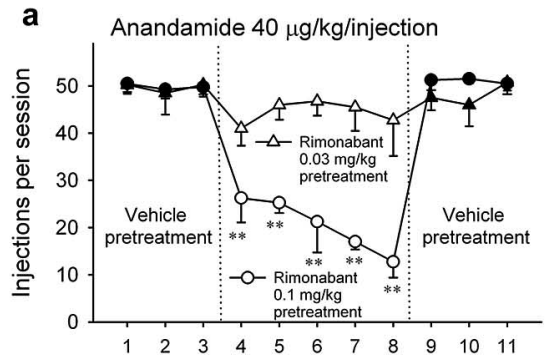

b

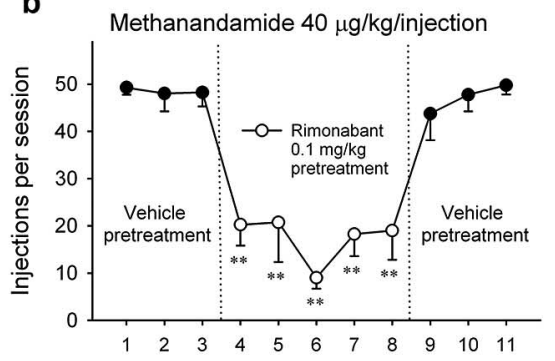

C Cocaine $30 \mu \mathrm{g} / \mathrm{kg} /$ injection

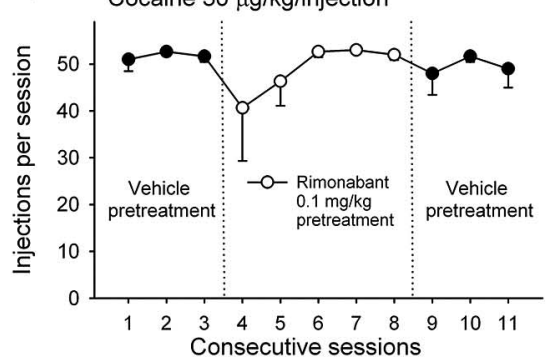

d

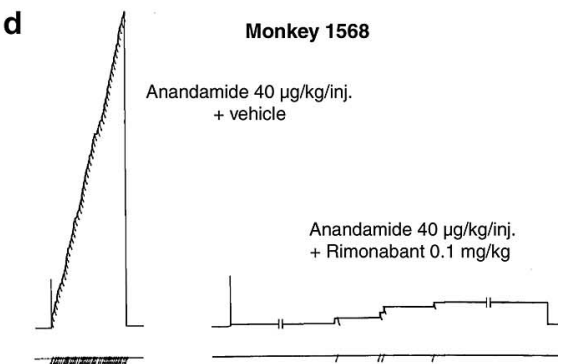

e

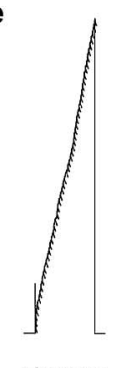

f

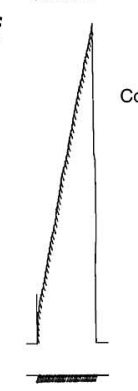

Monkey 6754

Methanandamide $40 \mu \mathrm{g} / \mathrm{kg} / \mathrm{inj}$. + vehicle
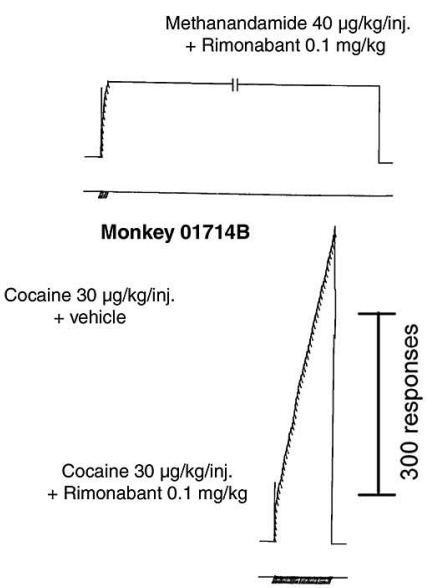

Figure 3. Effects of rimonabant on responding maintained by anandamide $(\boldsymbol{a})$, methanandamide $(\boldsymbol{b})$, or cocaine (c) injections over consecutive sessions. Numbers of injections per session after intramuscular pretreatment with vehicle (sessions 1-3 and $9-11$ ) or 0.03 or $0.1 \mathrm{mg} / \mathrm{kg}$ (sessions $4-8$ ) rimonabant are shown in the left column. Each point represents the mean \pm SEM from four $(\boldsymbol{a}, \boldsymbol{b})$ or three $(\boldsymbol{c})$ monkeys over the last three sessions. ${ }^{* *} p<0.01$, post hoc comparisons with the last session before pretreatment with rimonabant. Representative cumulative response records (for details, see Materials and Methods) from the last anandamide $(\boldsymbol{d})$, methanandamide $(\boldsymbol{e})$, or cocaine $(\boldsymbol{f})$ self-administration session with vehicle (session 3 ) or $0.1 \mathrm{mg} / \mathrm{kg}$ rimonabant pretreatment (session 8) are shown in the right column.

dopamine. Our finding that anandamide is actively selfadministered by squirrel monkeys provides the first direct evidence for activation of brain reward processes by an exogenously administered endogenous cannabinoid and suggests that release of anandamide in the brain could be part of the signaling of natural rewarding events.

The present finding that anandamide is an effective reinforcer of intravenous self-administration behavior in an animal model of human drug abuse suggests that medications that promote the actions of endogenously released cannabinoids could also activate brain reward processes and have the potential for abuse. This might be the case with medications that promote the actions of both anandamide and the more widely distributed endocannabinoid 2-arachidonylglycerol (2-AG) throughout the brain, e.g., by inhibiting their membrane transporter (Piomelli, 2003), resulting in widespread activation of cannabinoid $\mathrm{CB}_{1}$ receptors. However, it is believed that FAAH inhibitors promote the gradual accumulation of anandamide and augment $\mathrm{CB}_{1}$ signaling only in select brain areas in which FAAH-positive cell bodies are juxtaposed to axon terminals that contain $\mathrm{CB}_{1}$ receptors (Piomelli, 2003; Di Marzo et al., 2004). Thus, FAAH inhibitors, which do not affect inactivation of 2-AG, would not necessarily be selfadministered in a manner similar to our findings with rapid systemic injection of exogenous anandamide. Because there are no published reports on reinforcing effects of inhibitors of endocannabinoid transport or FAAH inhibitors, their abuse potential remains to be resolved. Intravenous selfadministration of anandamide by squirrel monkeys provides a novel procedure for studying the potential abuse liability of medications that activate endogenous cannabinoid systems and for investigating mechanisms involved in the reinforcing effects of endocannabinoids.

\section{References}

Abadji V, Lin S, Taha G, Griffin G, Stevenson LA, Pertwee RG, Makriyannis A (1994) (R)methanandamide: a chiral novel anandamide possessing higher potency and metabolic stability. J Med Chem 37:1889-1893.

Aceto MD, Scates SM, Razdan RK, Martin BR (1998) Anandamide, an endogenous cannabinoid, has a very low physical dependence potential. J Pharmacol Exp Ther 287:598-605.

Adams IB, Compton DR, Martin BR (1998) Assessment of anandamide interaction with the cannabinoid brain receptor: SR 141716A antagonism studies in mice and autoradiographic analysis of receptor binding in rat brain. J Pharmacol Exp Ther 284:1209-1217.

Breivogel CS, Griffin G, Di Marzo V, Martin BR (2001) Evidence for a new $G$ protein-coupled cannabinoid receptor in mouse brain. Mol Pharmacol 60:155-163.

Costa B, Vailati S, Colleoni M (1999) SR 141716A, a cannabinoid receptor antagonist, reverses the behavioural effects of anandamide-treated rats. Behav Pharmacol 10:327-331.

Costa B, Giagnoni G, Colleoni M (2000) Precipitated and spontaneous withdrawal in rats tolerant to anandamide. Psychopharmacology (Berl) 149:121-128.

Devane WA, Hanus L, Breuer A, Pertwee RG, Stevenson LA, Griffin G, Gibson D, Mandelbaum A, Etinger A, Mechoulam R (1992) Isolation and structure of a brain constituent that binds to the cannabinoid receptor. Science 258:1946-1949.

Di Marzo V, Berrendero F, Bisogno T, Gonzalez S, Cavaliere P, Romero J, Cebeira M, Ramos JA, Fernandez-Ruiz JJ (2000a) Enhancement of anandamide formation in the limbic forebrain and reduction of endocannabinoid contents in the striatum of delta9-tetrahydrocannabinoltolerant rats. J Neurochem 74:1627-1635.

Di Marzo V, Breivogel CS, Tao Q, Bridgen DT, Razdan RK, Zimmer AM, Zimmer A, Martin BR (2000b) Levels, metabolism, and pharmacological activity of anandamide in $\mathrm{CB}(1)$ cannabinoid receptor knockout mice: evidence for non- $\mathrm{CB}(1)$, non- $\mathrm{CB}(2)$ receptor-mediated actions of anandamide in mouse brain. J Neurochem 75:2434-2444.

Di Marzo V, De Petrocellis L, Fezza F, Ligresti A, Bisogno T (2002) Anandamide receptors. Prostaglandins Leukot Essent Fatty Acids 66:377-391.

Di Marzo V, Bifulco M, De Petrocellis L (2004) The endocannabinoid system and its therapeutic exploitation. Nat Rev Drug Discov 3:771-784.

Freund TF, Katona I, Piomelli D (2003) Role of endogenous cannabinoids in synaptic signaling. Physiol Rev 83:1017-1066.

Giuffrida A, Parsons LH, Kerr TM, Rodriguez de Fonseca F, Navarro M, Piomelli D (1999) Dopamine activation of endogenous cannabinoid signaling in dorsal striatum. Nat Neurosci 2:358-363.

Goldberg SR (1973) Comparable behavior maintained under fixed-ratio and second-order schedules of food presentation, cocaine injection or $\mathrm{d}$-amphetamine injection in the squirrel monkey. J Pharmacol Exp Ther 186:18-30.

Gonzalez S, Cascio MG, Fernandez-Ruiz J, Fezza F, Di Marzo V, Ramos JA (2002) Changes in endocannabinoid contents in the brain of rats chronically exposed to nicotine, ethanol or cocaine. Brain Res 954:73-81. 
Hajos N, Ledent C, Freund TF (2001) Novel cannabinoid-sensitive receptor mediates inhibition of glutamatergic synaptic transmission in the hippocampus. Neuroscience 106:1-4.

Jarbe TU, Lamb RJ, Lin S, Makriyannis A (2001) (R)-methanandamide and Delta 9-THC as discriminative stimuli in rats: tests with the cannabinoid antagonist SR-141716 and the endogenous ligand anandamide. Psychopharmacology (Berl) 156:369-380.

Justinova Z, Tanda G, Redhi GH, Goldberg SR (2003) Self-administration of Delta(9)-tetrahydrocannabinol (THC) by drug naive squirrel monkeys. Psychopharmacology (Berl) 169:135-140.

Ko MC, Terner J, Hursh S, Woods JH, Winger G (2002) Relative reinforcing effects of three opioids with different durations of action. J Pharmacol Exp Ther 301:698-704

Koob GF, Le Moal M (2001) Drug addiction, dysregulation of reward, and allostasis. Neuropsychopharmacology 24:97-129.

Ledent C, Valverde O, Cossu G, Petitet F, Aubert JF, Beslot F, Bohme GA, Imperato A, Pedrazzini T, Roques BP, Vassart G, Fratta W, Parmentier M (1999) Unresponsiveness to cannabinoids and reduced addictive effects of opiates in CB1 receptor knockout mice. Science 283:401-404.

Maldonado R, Rodriguez de Fonseca F (2002) Cannabinoid addiction: behavioral models and neural correlates. J Neurosci 22:3326-3331.

Mallet PE, Beninger RJ (1998) Delta9-tetrahydrocannabinol, but not the endogenous cannabinoid receptor ligand anandamide, produces conditioned place avoidance. Life Sci 62:2431-2439.

Pertwee RG (2004) Novel pharmacological targets for cannabinoids. Curr Neuropharmacol 2:9-29.

Piomelli D (2003) The molecular logic of endocannabinoid signalling. Nat Rev Neurosci 4:873-884.

Piomelli D (2004) The endogenous cannabinoid system and the treatment of marijuana dependence. Neuropharmacology 47 [Suppl 1]:359-367.

Rinaldi-Carmona M, Barth F, Heaulme M, Shire D, Calandra B, Congy C, Martinez S, Maruani J, Neliat G, Caput D, Ferrara P, Soubrie P, Breliere JC, Le Fur G (1994) SR141716A, a potent and selective antagonist of the brain cannabinoid receptor. FEBS Lett 350:240-244.

Romero J, Garcia-Palomero E, Lin SY, Ramos JA, Makriyannis A, Fernandez-
Ruiz JJ (1996) Extrapyramidal effects of methanandamide, an analog of anandamide, the endogenous CB1 receptor ligand. Life Sci 58:1249-1257.

Sanchis-Segura C, Cline BH, Marsicano G, Lutz B, Spanagel R (2004) Reduced sensitivity to reward in CB1 knockout mice. Psychopharmacology (Berl) 176:223-232.

Smith PB, Compton DR, Welch SP, Razdan RK, Mechoulam R, Martin BR (1994) The pharmacological activity of anandamide, a putative endogenous cannabinoid, in mice. J Pharmacol Exp Ther 270:219-227.

Solinas M, Goldberg SR (2005) Motivational effects of cannabinoids and opioids on food reinforcement depend on simultaneous activation of cannabinoid and opioid systems. Neuropsychopharmacology, in press.

Solinas M, Panlilio LV, Antoniou K, Pappas LA, Goldberg SR (2003) The cannabinoid CB1 antagonist N-piperidinyl-5-(4-chlorophenyl)-1-(2,4dichlorophenyl)-4-methylpyrazole-3-carboxamide (SR-141716A) differentially alters the reinforcing effects of heroin under continuous reinforcement, fixed ratio, and progressive ratio schedules of drug selfadministration in rats. J Pharmacol Exp Ther 306:93-102.

Tanda G, Goldberg SR (2003) Cannabinoids: reward, dependence, and underlying neurochemical mechanisms-a review of recent preclinical data. Psychopharmacology (Berl) 169:115-134.

Tanda G, Munzar P, Goldberg SR (2000) Self-administration behavior is maintained by the psychoactive ingredient of marijuana in squirrel monkeys. Nat Neurosci 3:1073-1074.

van der Stelt M, Di Marzo V (2003) The endocannabinoid system in the basal ganglia and in the mesolimbic reward system: implications for neurological and psychiatric disorders. Eur J Pharmacol 480:133-150.

Wiley JL, LaVecchia KL, Karp NE, Kulasegram S, Mahadevan A, Razdan RK, Martin BR (2004) A comparison of the discriminative stimulus effects of $\operatorname{Delta}(9)$-tetrahydrocannabinol and O-1812, a potent and metabolically stable anandamide analog, in rats. Exp Clin Psychopharmacol 12:173-179.

Wise RA (2004) Dopamine, learning and motivation. Nat Rev Neurosci 5:483-494.

Zygmunt PM, Petersson J, Andersson DA, Chuang H, Sorgard M, Di Marzo V, Julius D, Hogestatt ED (1999) Vanilloid receptors on sensory nerves mediate the vasodilator action of anandamide. Nature 400:452-457. 